\title{
Article \\ New Insights on the Stradivari "Coristo" Mandolin: A Combined Non-Invasive Spectroscopic Approach
}

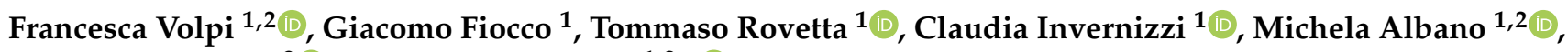 \\ Maurizio Licchelli ${ }^{3}$ (D) and Marco Malagodi ${ }^{1,2, *(\mathbb{D})}$
}

1 Arvedi Laboratory of Non-Invasive Diagnostics, CISRiC, University of Pavia, Via bell'Aspa 3, 26100 Cremona, Italy; francesca.volpi@unipv.it (F.V.); giacomo.fiocco@unipv.it (G.F.); tommaso.rovetta@unipv.it (T.R.); claudia.invernizzi@unipv.it (C.I.); michela.albano@unipv.it (M.A.)

2 Department of Musicology and Cultural Heritage, University of Pavia, Corso Garibaldi, 178, 26100 Cremona, Italy

3 Department of Chemistry, University of Pavia, Via Taramelli 12, 27100 Pavia, Italy; maurizio.licchelli@unipv.it

* Correspondence: marco.malagodi@unipv.it

Citation: Volpi, F.; Fiocco, G.;

Rovetta, T.; Invernizzi, C.; Albano, M.; Licchelli, M.; Malagodi, M. New Insights on the Stradivari "Coristo" Mandolin: A Combined NonInvasive Spectroscopic Approach Appl. Sci. 2021, 11, 11626. https:// doi.org/10.3390/app112411626

Academic Editor: Wolfgang Elsaesser

Received: 30 October 2021

Accepted: 2 December 2021

Published: 7 December 2021

Publisher's Note: MDPI stays neutral with regard to jurisdictional claims in published maps and institutional affiliations.

Copyright: (c) 2021 by the authors. Licensee MDPI, Basel, Switzerland. This article is an open access article distributed under the terms and conditions of the Creative Commons Attribution (CC BY) license (https:// creativecommons.org/licenses/by/ $4.0 /)$.

\begin{abstract}
In this work, one of the two existing mandolins made by Antonio Stradivari has been investigated for the first time, as a rare exemplar of the lesser-known class of plucked string instruments. The mandolin was studied by non-invasive reflection Fourier transformed infrared (FT-IR) spectroscopy and X-ray fluorescence (XRF) on different areas previously selected by UV-induced fluorescence imaging. The analytical campaign was aimed at (i) identifying the materials used by Stradivari in the finishing of the mandolin, (ii) comparing these materials with those traditionally used in violin making, and (iii) increasing the knowledge of materials and techniques applied by Stradivari in the rare production of plucked string instruments. The combined spectroscopic approach allowed us to hypothesize original materials and finishing procedures similar to those used in violin making: a possible sizing treatment of the wood with protein-based materials and silicates, externally coated with an oil-resin varnish. XRF results were essential to support FT-IR findings and to detect possible iron-based pigments in the finishing layers. Moreover, it permitted us to distinguish original areas from the restored areas, including the purflings on the top plate and the varnished area on the treble side of the mandolin for which the originality was assumed.
\end{abstract}

Keywords: Stradivari; musical instrument; mandolin; varnish; coatings; multi-layered structure; XRF; reflection FT-IR; spectroscopy

\section{Introduction}

In recent decades, research efforts have dramatically advanced the knowledge of historical musical instruments in terms of finishing techniques and analytical approaches applied to characterize the utilized materials [1,2], focusing attention on bowed string instruments of the Cremonese tradition between the 17th and 18th centuries. The most famous luthier of this period is the renowned Master Antonio Stradivari (Cremona, 1644-1737), who left numerous excellent musical instruments and several traces of his works, including drawings, molds, and tools [3], but not written sources of his finishing techniques. For this reason, the role of scientific investigation is crucial to characterize the finish of the instruments, which was revealed to be a complex multi-layered coating system where each layer is likely representative of a specific step of the finishing procedure.

Regarding the composition of the excellent Stradivari's varnish, chemical analysis performed on several violins made by the great Master, dated from 1679 to 1724, often identified a mixture of siccative oil and natural resins [4-7]. In some cases, the varnish was enriched with low concentrations of mineral pigments, mostly Fe-based earth or organic colorants, to give a slightly colorful appearance while keeping the transparency and glossy effect [8-11]. Bone ash and pumice have been also suggested as minerals added to stabilize 
and increase the rate of drying of the varnish [12]. Under the varnish, a ground layer was often detected and described as a mixture of protein-based materials with a dispersion of inorganic fillers, such as silicates or sulfates [13]. Moreover, the presence of a pre-treatment of the wood has been suggested by several authors, although it was barely detected and identified [14-16].

The contribution of Antonio Stradivari to instrument making is not only limited to bowed string instruments, i.e., violin, viola, and cello, but also includes plucked string instruments such as guitars, lutes, harps, and mandolins. His wide production is confirmed by tens of drawings and molds of different kinds of musical instruments currently conserved in the Museo del Violino in Cremona, Italy [3]. Among the plucked string instruments of Stradivari, only two mandolins are known to have survived: the oldest, named "The Cutler-Callen", made in 1680 and conserved in the National Music Museum in Vermillion, South Dakota, USA [16]; and the "Coristo" mandolin that was made between 1700 and 1710, currently conserved in the Museo del Violino in Cremona (Figure 1; highresolution images are reported in Figures S1-S6 in Supplementary Information). The latter extraordinary example of the Stradivari musical instrument is the object of this study.
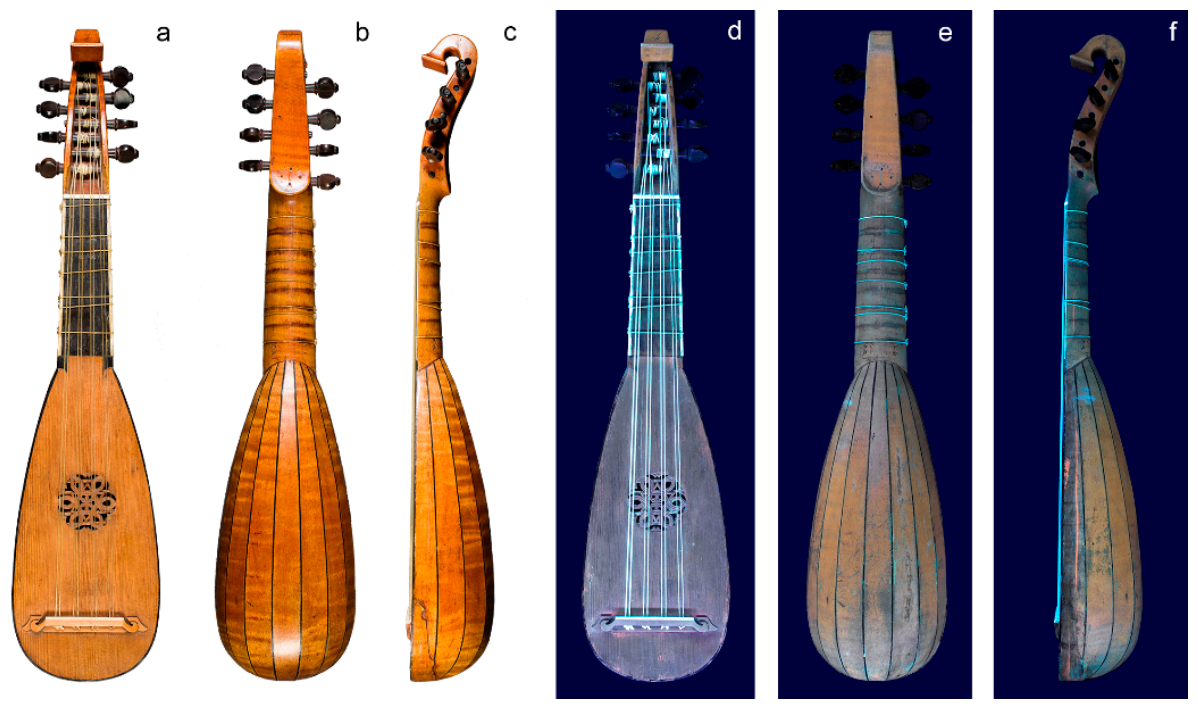

Figure 1. Images in visible light $(\mathbf{a}-\mathbf{c})$, and UV-induced fluorescence $(\mathbf{d}-\mathbf{f})$ of the front, the back, and the right treble side of the "Coristo" mandolin.

From historical sources, we know that the mandolin probably derived from an ancient Arab instrument similar to a small lute, and it succeeded in Italy principally over the 17 th and 18th centuries due to an important production of music made on purpose for this type of instrument $[17,18]$. Concerning the materials used to finish a mandolin, though, little information is available [19]. In this view, for the first time, the analytical results on the "Coristo" mandolin made by Stradivari are here presented, using a combined approach of three non-invasive techniques: UV-induced fluorescence imaging, reflection Fourier transformed infrared (FT-IR) spectroscopy, and X-ray fluorescence (XRF). These complementary techniques were selected based on the capability of UV, IR, and X-ray radiations to obtain information from different organic and inorganic materials, allowing us to non-invasively characterize the coating system. The goals of the study were to: (i) identify the materials used by Stradivari in the finishing processes of the mandolin, (ii) compare these materials with those used in violin finishing, and (iii) increase the knowledge of materials and techniques applied by the Master in the less-explored class of plucked string instruments. 


\section{Materials and Methods}

\subsection{The "Coristo" Mandolin}

The "Coristo" mandolin is currently owned by a private collector. It belonged to an American museum, which sent it for sale by auction in the 1970s. As described by the collector Beare, when the mandolin was sold, "it showed a neglected state of conservation, it was dirty, showing several—not original—added layers of varnish. It was successively restored, and the added varnishes were removed to show again the typical Stradivari varnish" [18]. Based on a preliminary observation of the surface with visible and UV light and the investigation of the structural features of the mandolin through X-ray radiography (not reported in this paper), a good state of conservation characterized the instrument when it was analyzed.

\subsection{The Methodological Approach}

The deterioration of an ancient musical instrument can cause varnish detachments or thinning of the coating, especially in correspondence with worn-out areas produced by contact with the musician, exposing the inner layers. To approach the non-invasive stratigraphic investigation of the Stradivari's mandolin, without any sampling, the analyses were performed on both well-conserved and worn-out areas to give insight into the materials and methods used by the Master. A preliminary observation of the instrument surface was performed in visible light while UV-induced fluorescence imaging was used to highlight variations in the optical properties, likely due to chemical inhomogeneities of the materials and potentially the presence of additional layers [20,21], or even the thinning of the existing one. Finally, the selected areas of interest were investigated by two spectroscopic techniques, namely $\mathrm{X}$-ray fluorescence (XRF) $[22,23]$ and reflection Fourier transform infrared (FT-IR) $[5,24,25]$, to achieve both elemental and molecular information, respectively.

A Nikon D4 full-frame digital camera (Minato, Tokyo, Japan) equipped with a $50 \mathrm{~mm}$ $\mathrm{f} / 1.4$ Nikkor objective was used. Visible light images (f/11 and ISO 100) were obtained using a Softbox LED lamp, while UV-induced fluorescence ones (30 s exposure time, f/11, and ISO 400) were collected by illuminating the samples with two Philips TL-D 36W BBL IPP low-pressure $\mathrm{Hg}$ tubes (emission peak at $365 \mathrm{~nm}$ ). In order to highlight and label areas of interest on the surface of the instrument, the UV Analyzer software, self-developed by the Arvedi Laboratory at the University of Pavia, was used [26-28].

Reflection FT-IR spectra were recorded using the Alpha portable spectrometer (Bruker Optics, Etringen, Germany; Billerica, MA, USA) equipped with a SiC globar source, a permanently aligned RockSolid interferometer with gold mirrors, and a DLaTGS detector. Measurements were performed at a working distance of $15 \mathrm{~mm}$ by an external reflectance module with an optical layout of $23^{\circ} / 23^{\circ}$. Pseudo-absorbance spectra $(\log (1 / R)$; $\mathrm{R}=$ reflectance) were acquired between 7500 and $375 \mathrm{~cm}^{-1}$ with a spectral resolution of $4 \mathrm{~cm}^{-1}$ and acquisition time of $1 \mathrm{~min}$. A gold flat mirror was used as the background. Reflection spectra were transformed to absorbance spectra by applying the Kramers-Kronig (KK) algorithm, included in the OPUS 7.2 software package, and the mid-IR spectral range is exhibited in the figures. The FT-IR analytical spots acquired on the top plate, shell, and treble side of the mandolin are shown in Figure S7 (green circles) in Supplementary Information.

$\mathrm{X}$-ray fluorescence spectra were acquired by a portable energy-dispersive XRF spectrometer ELIO (Bruker Corporation, Billerica, MA, USA). The excitation source works with an $\mathrm{Rh}$ anode and the beam is collimated to a spot diameter on the sample surface of about $1.3 \mathrm{~mm}$. XRF measurements were carried out by fixing the tube voltage at $40 \mathrm{kV}$ and the tube current at $80 \mu \mathrm{A}$ for a measured time of $480 \mathrm{~s}(8 \mathrm{~min})$ and setting acquisition channels at 2048. The data were processed by ELIO 1.6.0.29 software (Bruker Corporation, Billerica, MA, USA). To qualitatively estimate the abundance of the elements, the net area count of each element was normalized by dividing the $\mathrm{K} \alpha$ peaks (except for $\mathrm{Ba}$ and $\mathrm{Pb}$ where $\mathrm{L} \alpha$ was used) by the averaged net area counts of the coherent scattering peak of Rh. It is worth clarifying that due to the working conditions used in this study, i.e., air as medium or the presence of multi-layered substrates with variable thicknesses, the detection of light 
elements such as silicon, sulfur, and phosphor may result underestimated because their secondary radiations can be severely attenuated by the air and/or any dense material superimposed $[10,29]$. At any event, even though a fully semiquantitative analysis was not possible, the use of the same geometry, voltage, and current conditions for different points of analysis allowed a reasonable qualitative comparison. The XRF analytical spots acquired on the top plate, shell, and treble side of the mandolin are shown in Figure S7 (red squares) in Supplementary Information.

\section{Results and Discussion}

\subsection{Selection of the Areas of Analysis}

Based on the UV-induced fluorescence colors of the mandolin surface in Figure 1, seven areas of interest were highlighted through the UV Analyzer software shown in Figure 2. In the top plate, two UV-induced fluorescence colors were observed: a fairly homogeneous blue hue over the majority of the plate and some light-brown spots. These two areas were identified by the UV Analyzer in Figure 2a as A and B, respectively. The well-conserved varnished area on the shell of the mandolin showed a yellow-brown UV-induced fluorescence color, while worn areas displayed a blue-greenish fluorescence, respectively identified as $C$ and $D$ areas in Figure $2 b$. In correspondence with the treble side of the mandolin (Figure 1f), an orange UV fluorescent area appeared, which was identified as area E in Figure 2c. The purflings on the top plate and shell which showed a dark UV-induced fluorescence color were identified as F in Figure 2.
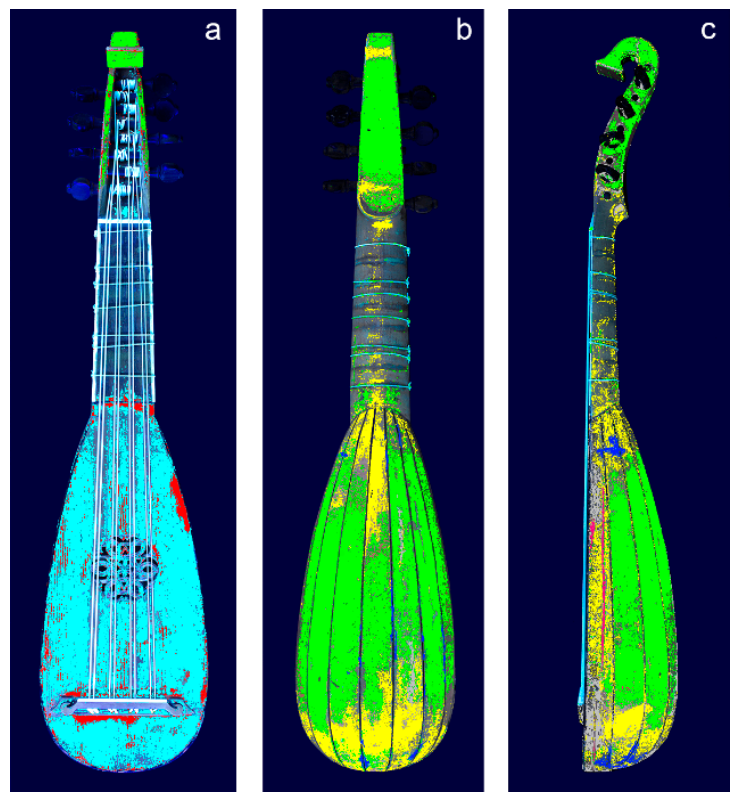

Figure 2. Images of the top plate (a), shell (b), and treble side (c) processed by the UV Analyzer. The colors correspond to different areas of interest according to the UV-induced fluorescence color: area A in light-blue, area B in red, area C in green, area D in yellow, area E in magenta, and area F (purflings) in black.

\subsection{Reflection FT-IR Spectroscopic Analysis}

All the reflection FT-IR spectra acquired on the top plate of the mandolin (area A in Figure 2) show similar features, where the prevalent signals derive from the wooden substrate. Typical spectral features of wood include a broad $\mathrm{OH}$ bond vibration band at around $3350 \mathrm{~cm}^{-1}$, weak and poorly resolved $\mathrm{CH}$ stretching vibrations around 2900 and $2800 \mathrm{~cm}^{-1}$, and the bands at $1720 \mathrm{~cm}^{-1}$ attributed to unconjugated $\mathrm{C}=\mathrm{O}$. In addition, wood shows intense multiple signals between 1150 and $1050 \mathrm{~cm}^{-1}$ assigned to the stretching of C-O bonds and glucose ring stretches in cellulose [30,31]. The bands attributed to the wood are marked with black rhombus in the KK-transformed spectrum in Figure 3a. In addition, 
poorly resolved features at $1660-1650 \mathrm{~cm}^{-1}$ and $1550 \mathrm{~cm}^{-1}$ appeared in the KKT spectra (marked with a triangle in Figure 3a,b), suggesting the presence of proteinaceous compounds at $1660 \mathrm{~cm}^{-1}$ (amide I) and $1550 \mathrm{~cm}^{-1}$ (amide II) [13,32]. In the pseudo-absorbance spectra, the Restrahlen band at $1015 \mathrm{~cm}^{-1}$ (marked with an asterisk in Figure 3a,b) suggests the presence of silicates [33,34]. Furthermore, the detection of sharp $\mathrm{CH}$ stretching bands at $2920 \mathrm{~cm}^{-1}$ and $2850 \mathrm{~cm}^{-1}$, particularly intense in the right and bottom areas of the top plate, along with $\mathrm{CH}$ bending bands between 1400 and $1350 \mathrm{~cm}^{-1}$, and a weak and not-resolved $\mathrm{C}=\mathrm{O}$ signal around $1710 \mathrm{~cm}^{-1}$ appearing as a shoulder in the KKT spectra of Figure 3, could possibly suggest the additional presence of organic materials. However, a clear identification of this class of compounds was not permitted due to poor intensity of the bands and the predominance of wood signals in the spectral profile. Some KKT spectra collected on area B, highlighted in red in Figure 2, display sharp peaks at $1260 \mathrm{~cm}^{-1}$ and around $800 \mathrm{~cm}^{-1}$ (marked with circles in Figure $3 \mathrm{~b}$ ), which may correspond to $\mathrm{Si}-\mathrm{CH}_{3}$ stretching bonds [35], presumably related to a modern silicone-based product used to superficially treat and polish the wood. Organosilicon compounds were also revealed on the "San Lorenzo" violin made in 1718 by Stradivari as a residue of a contemporary polishing treatment [11].
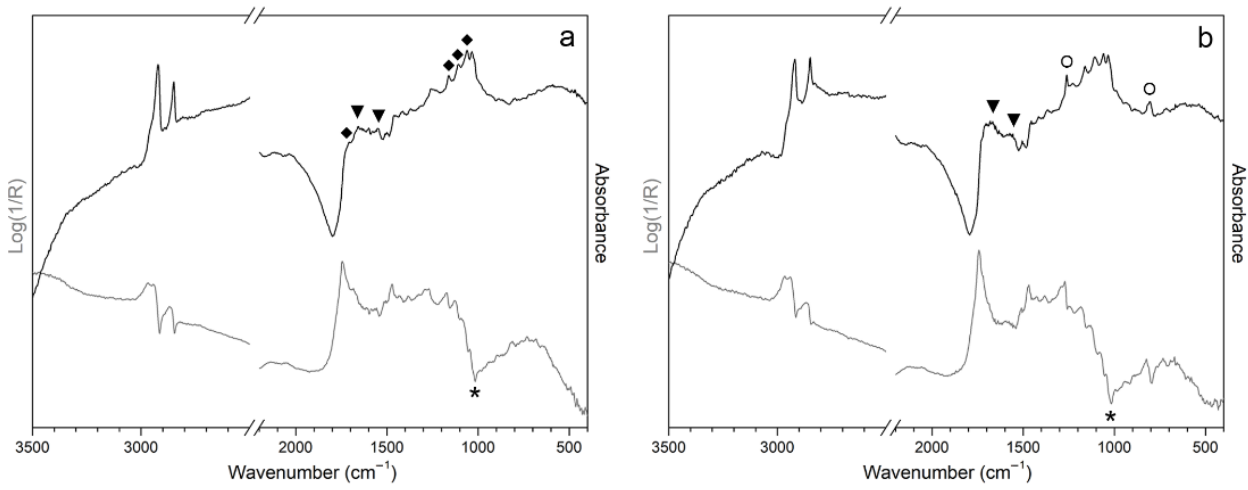

Figure 3. Reflection FT-IR spectra in pseudo-absorbance (grey line) and after KK transform (black line) acquired on area A (a) and B (b) of the top plate as identified by the UV Analyzer in Figure 2a. Markers for proteins (triangle), wood (black rhombus), silicates (asterisk), and silicon-based material (circle) are displayed.

The FT-IR spectrum representative of the well-conserved areas of the shell (area C in Figure $2 b$ ) exhibits the signals of an oil-resin varnish, likely linseed oil in mixture with a terpenic resin $[6,28,31]$, with typical $\mathrm{CH}$ stretching bands at $2920 \mathrm{~cm}^{-1}$ and $2850 \mathrm{~cm}^{-1}$, $\mathrm{CH}$ bending at 1462,1376 , and $1385 \mathrm{~cm}^{-1}$, and a broad $\mathrm{C}=\mathrm{O}$ stretch around $1715 \mathrm{~cm}^{-1}$ in the KKT spectrum (Figure 4a) [31,36,37]. The carbonyl band is broadened due to a double contribution from the ester groups (oil) around $1740 \mathrm{~cm}^{-1}$ and the acid groups (resin) around 1715-1690 $\mathrm{cm}^{-1}$, which broadens with degradation and oxidation [38-40]. Interestingly, the spectrum acquired on the worn-out areas of the shell (area D in Figure $2 b$ ) shows signals increasing around 1650 and $1550 \mathrm{~cm}^{-1}$, in the KK-transformed spectrum, and around $1015 \mathrm{~cm}^{-1}$ in the pseudo-absorbance spectrum, marked in Figure $4 \mathrm{~b}$, previously observed on the top plate, respectively ascribable to protein-based products and silicates used as sizing treatment. The detection and identification of proteins and silicates on wood is still a discussed topic in scientific literature. However, in accordance with many studies, the detection of these compounds in an area where the varnish was almost totally detached or significantly thinned by the use of the mandolin during its history seems to support fairly well the hypothesis of a wood sizing treatment applied before varnishing. Therefore, it is reasonable to assume that an oil-resin varnish was applied on the surface of the mandolin and, where the varnish layer is consumed, the underneath treated wooden surface is revealed. 

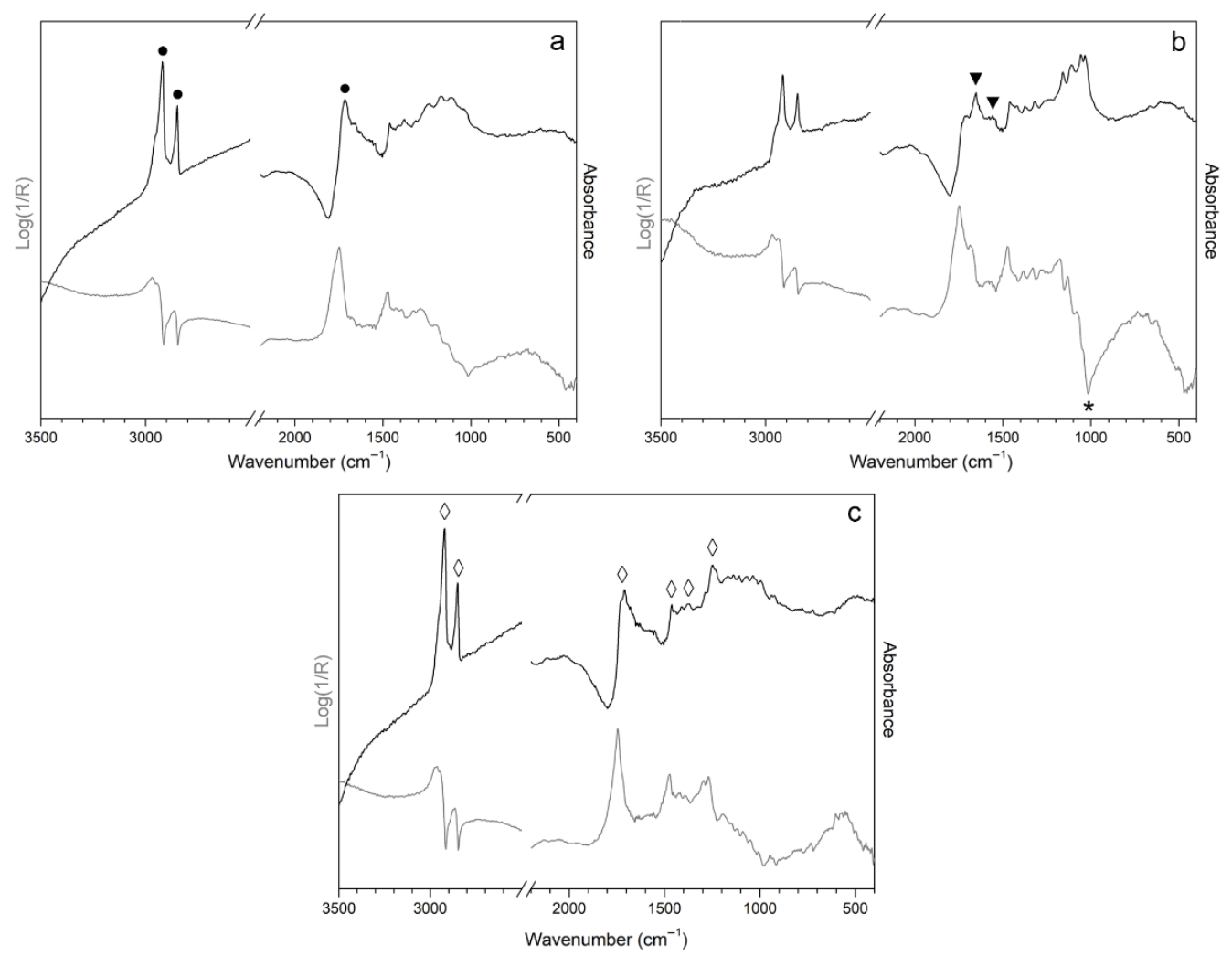

Figure 4. Reflection FT-IR spectra in pseudo-absorbance (grey line) and after KK transform (black line) acquired on C (a), D (b), and E (c) areas of the shell as identified by the UV Analyzer in Figure 2. Markers for oil-resin varnish (circle), proteins (triangle), silicates (asterisk), and shellac (white rhombus) are displayed.

Finally, area E, highlighted in magenta in Figure 2c, corresponds fairly well with the reference spectrum of shellac (Figure 4c). This animal resin, excreted from lac beetles, shows typical $\mathrm{CH}$ stretching bands at $2920 \mathrm{~cm}^{-1}$ and $2857 \mathrm{~cm}^{-1}, \mathrm{CH}_{2}$ scissoring bands at $1465 \mathrm{~cm}^{-1}$, a C $=\mathrm{O}$ stretching doublet at $1735 \mathrm{~cm}^{-1}$ and $1715 \mathrm{~cm}^{-1}$ due to the ester and acid groups, respectively [32], and the characteristic intense peak at $1252 \mathrm{~cm}^{-1}$ due to C-O stretches of ester bonds [4]. Shellac was used in Italy as early as the 18th century, and it is also commonly used in mixture with alcohol in the so-called French polish technique in musical instruments conservation to enhance the aesthetic features of the varnish [41].

\subsection{XRF Results}

A qualitative evaluation of XRF data acquired on different areas of the mandolin is reported in Table 1. The results obtained on the top plate and the shell reveal high counts of potassium $(\mathrm{K})$ and calcium $(\mathrm{Ca})$. These elements are naturally found in wood, as displayed in Figure 5a; however, their increment along with not negligible counts of sulphur (S) and phosphorus (P) and the signals of proteinaceous material obtained from FT-IR analysis (Section 3.2) could imply the presence of protein-based wood treatments, such as animal glue and/or potassium/calcium caseinate, which could have been applied before varnishing the surface [10]. The addition of bone ash or pumice to the varnish, as proposed by other authors [12], could explain the increment of $\mathrm{Ca}, \mathrm{K}$, and P, but FT-IR analysis did not reveal hydroxyapatite, which is the main constituent of bone, while the presence of silicate, also contained in pumice, seemed to be likely located within the inner layer rather than in the varnish. 
Table 1. List of the elements detected by XRF in different areas of the mandolin, listed according to their normalized peak area counts, from the most $(>10)$ to the least $(<1)$ abundant. The sign "_" in the table means "no elements".

\begin{tabular}{cccc}
\hline Area of the Mandolin & $>\mathbf{1 0}$ & $\mathbf{1 - 1 0}$ & $<\mathbf{1}$ \\
\hline Top plate & - & $\mathrm{K}, \mathrm{Ca}$ & $\mathrm{Si}, \mathrm{P}, \mathrm{S}, \mathrm{Ti}, \mathrm{Cr}, \mathrm{Mn}, \mathrm{Fe}, \mathrm{Ni}, \mathrm{Cu}, \mathrm{Zn}, \mathrm{Sr}, \mathrm{Pb}$ \\
Shell & - & $\mathrm{K}, \mathrm{Ca}$ & $\mathrm{Si}, \mathrm{P}, \mathrm{Ti}, \mathrm{Fe}, \mathrm{Cu}, \mathrm{Pb}$ \\
Restoration material on the treble side & - & $\mathrm{Ca}, \mathrm{Fe}, \mathrm{Zn}$ & $\mathrm{S}, \mathrm{K}, \mathrm{Cr}, \mathrm{Mn}, \mathrm{Ni}, \mathrm{Cu}, \mathrm{Sr}, \mathrm{Ba}, \mathrm{Pb}$ \\
Purfling on the shell (SP) & $\mathrm{Fe}$ & $\mathrm{K}, \mathrm{Ca}$ & $\mathrm{Si}, \mathrm{P}, \mathrm{S}, \mathrm{Ti}, \mathrm{Cr}, \mathrm{Mn}, \mathrm{Cu}, \mathrm{Zn}, \mathrm{Sr}, \mathrm{Pb}$ \\
Fingerboard & $\mathrm{Fe}$ & $\mathrm{K}, \mathrm{Ca}$ & $\mathrm{Si}, \mathrm{P}, \mathrm{S}, \mathrm{Ti}, \mathrm{Mn}, \mathrm{Cu}, \mathrm{Zn}, \mathrm{Sr}, \mathrm{Pb}$ \\
Purfling on the top plate (TP) & - & $\mathrm{K}, \mathrm{Ca}, \mathrm{Fe}$ & $\mathrm{Si}, \mathrm{P}, \mathrm{S}, \mathrm{Ti}, \mathrm{Cr}, \mathrm{Mn}, \mathrm{Ni}, \mathrm{Cu}, \mathrm{Zn}, \mathrm{Br}, \mathrm{Sr}, \mathrm{Pb}$ \\
\hline
\end{tabular}
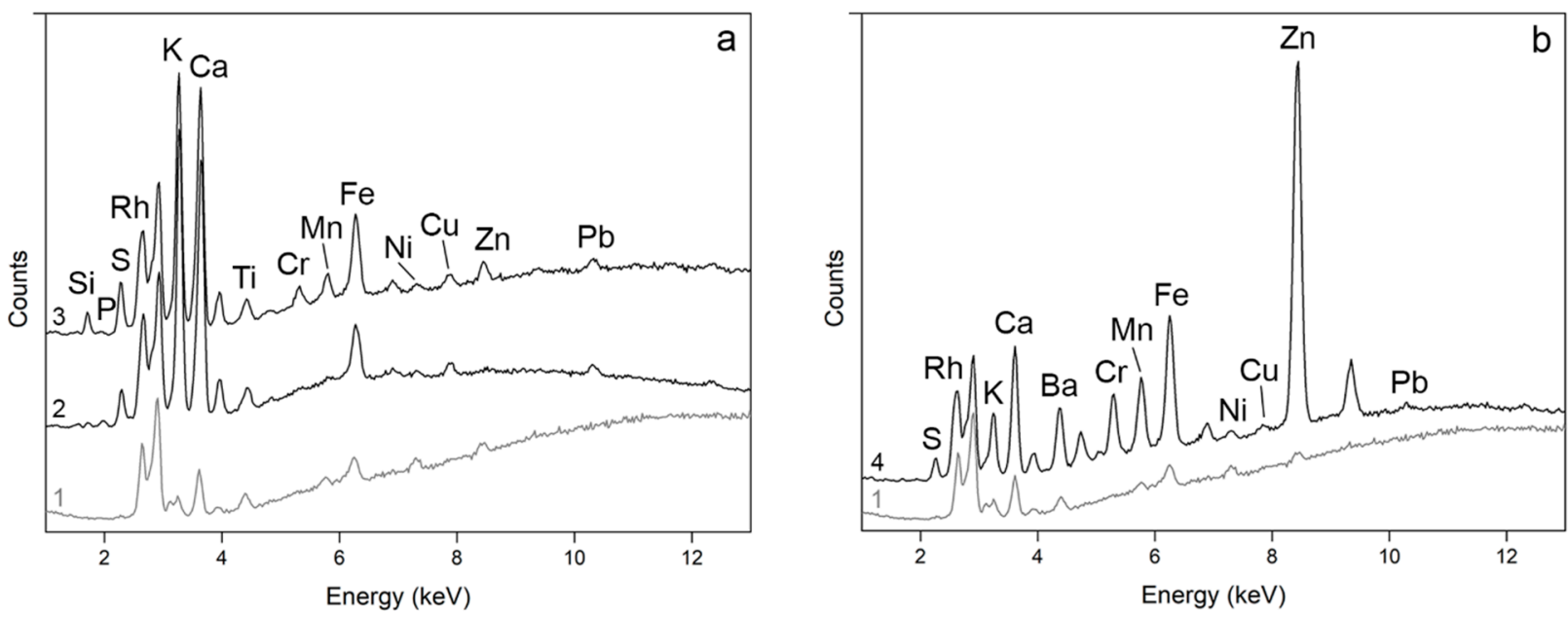

Figure 5. XRF representative spectra acquired on the top plate and the shell (a) and on the treble side of the mandolin (b). Numbers refer to different XRF spectra collected on Picea abies reference wood (1), areas A (2), C (3), and E (4) as identified through the UV Analyzer in Figure 2.

The detection of manganese $(\mathrm{Mn})$ in the top plate, in combination with iron $(\mathrm{Fe})$, may suggest the use of umber earth pigment, which is composed mainly of Fe and Mn oxides [41]. Conversely, no Mn was detected on the well-conserved areas of the shell. The presence of zinc $(\mathrm{Zn})$, nickel $(\mathrm{Ni})$, and chromium $(\mathrm{Cr})$ was detected only on the top plate and not on the shell and could be related to pollutants. Silicon (Si) was revealed in each point of analysis, both on the top plate and the shell. Although the related counts may be severely underestimated, the occurrence of silicon can be ascribable to silicate-based particles, as highlighted also by the results obtained through reflection FT-IR and described in Section 3.2 (a schematic overview of the results is reported in Table S1 in Supplementary Information). Lead $(\mathrm{Pb})$ was always detected and its presence could imply, according to the literature, the use of oils or oil-resin products, since $\mathrm{Pb}$-based siccative agents, e.g., massicot $(\mathrm{PbO})$ and white lead $\left(2 \mathrm{PbCO}_{3} \cdot \mathrm{Pb}(\mathrm{OH})_{2}\right)$, were added to accelerate the drying of oil [42-44].

The XRF data acquired on area $\mathrm{E}$ of the treble side of the mandolin are displayed in Figure $5 b$, showing remarkable differences from those acquired either on the top plate or the shell of the mandolin. $\mathrm{Zn}$ together with barium (Ba) could suggest the presence of lithopone, a mixture of $\mathrm{ZnS}$ and $\mathrm{BaSO}_{4}$ [45] used since the early 19th century in cold-water paints, although this hypothesis was not supported by FT-IR. Furthermore, in the same spot, $\mathrm{Fe}, \mathrm{Cr}$, and $\mathrm{Mn}$ increase in counts, likely suggesting the addition of a pigment in the finishing treatment. These results enabled us to hypothesize the application of an additional colored and pigmented coat on worn areas to resemble the original appearance [11]. To deepen the investigation of the complex stratigraphies present in this type of work of art, i.e., a historical musical instrument, high-performance techniques such as XRF mapping, micro-XRD, and micro-tomography at synchrotron facilities would be considered along with grazing-angle methods. 
The purfling analyzed on the shell (SP), as well as the fingerboard (FB), show Fe counts one order of magnitude greater than all the other analyzed areas. In addition, $\mathrm{S}, \mathrm{Cu}$, and Zn signals increase, suggesting that wood was probably dyed with iron-gall ink, which contains mineral components such as iron sulfate and minor portions of copper sulfate and traces of zinc impurities. In ancient times, indeed, dyeing wood was a very widespread practice to obtain substitutes for the rare, hard-to-work, and expensive ebony $[19,44,46,47]$. When compared to SP and FB in Figure 6a, the purflings on the top plate (TP_1 and TP_2, respectively) show lower counts of $\mathrm{Fe}, \mathrm{Cu}$, and $\mathrm{Zn}$, reported as $\mathrm{Fe} / \mathrm{Cu}$ and $\mathrm{Cu} / \mathrm{Zn}$ ratios in Figure $6 \mathrm{~b}$, likely due to the use of naturally black wood such as ebony. Moreover, bromide (Br) was detected in TP_1 and TP_2, and this occurrence led us to hypothesize the application of methyl bromide during a fumigation pest treatment, as typical from the 1930s to modern times [48]. In the "Coristo" mandolin, the detection of Br occurred only in the purflings on the top plate; hence it is reasonable to assume that only those decorative elements were replaced with modern fumigated wood.

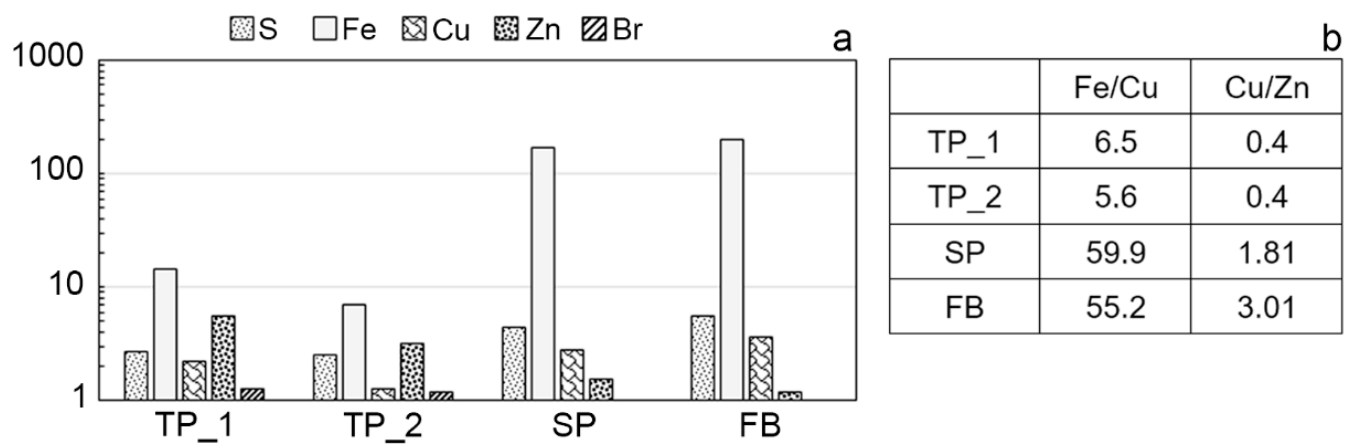

Figure 6. Estimation of elements detected by XRF on the top plate purflings (TP_1 and TP_2), on the shell purflings between the staves (SP), and on the fingerboard (FB). The values correspond to the net area counts of five different peaks (S-, Fe-, $\mathrm{Cu}-, \mathrm{Zn}-$, and $\mathrm{Br}-\mathrm{K} \alpha$ ) divided by net area counts of the peak of $\mathrm{Rh}-\mathrm{K} \alpha$, and they are displayed in a logarithmic scale (a). Elemental ratios calculated from net peak area counts $(\mathbf{b})$.

\section{Conclusions}

This study presents the first analytical results obtained on the "Coristo" mandolin, one of the two existing mandolins made by Antonio Stradivari, through the combination of XRF and reflection FT-IR spectroscopic non-invasive techniques. The results revealed that the shell of the instrument was finished with an oil-resin varnish, as already identified in previous research on violins and other bowed string instruments made by Stradivari, while the top plate was left probably unvarnished, although FT-IR spectra revealed organic materials difficult to characterize. A proteinaceous sizing with silicates as inorganic fraction was detected both on the top plate and the worn areas of the shell, suggesting a treatment of the wood, in accordance with the findings in other Stradivari instruments. In addition, residues of posthumous maintenance treatments were detected in some spots on the top plate and on the treble side, where shellac varnish was used along with fillers and ironbased pigments to resemble the original surface. Regarding the black purflings on the top plate and between the staves of the shell, we characterized two different elemental compositions. The purflings on the shell were made of wood dyed with iron-gall ink rather than the more expensive and exotic ebony. The purflings on the top plate were probably substituted in modern times with naturally black wood, likely ebony, fumigated with methyl bromide on the basis of the detection of bromide limited to this part of the mandolin. According to the non-invasive results achieved so far, we can conclude that the materials and finishing procedures used in the Stradivari's mandolin were the same as those used in violins; therefore, the typical features of the workshop are also recognizable in plucked string instruments. 
Supplementary Materials: The following are available online at https:/ /www.mdpi.com/article/ 10.3390/app112411626/s1, Figure S1: Image at high resolution in visible light of the front of the "Coristo" mandolin, Figure S2: Image at high resolution in visible light of the shell of the "Coristo" mandolin, Figure S3: Image at high resolution in visible light of the treble side of the "Coristo" mandolin, Figure S4: Image at high resolution in UV light of the front of the "Coristo" mandolin, Figure S5: Image at high resolution in UV light of the shell of the "Coristo" mandolin, Figure S6: Image at high resolution in UV light of the treble side of the "Coristo" mandolin, Figure S7: UV images of the front (a), the shell (b), ande the treble side (c) with the FT-IR and XRF analytical spots market with green circles and red squares, respectively, Table S1: Summary of the findings achieved with UV-vis Imaging, Reflection FT-IR and XRF.

Author Contributions: Conceptualization, F.V., G.F., T.R. and M.M.; methodology, F.V., G.F., T.R. and C.I.; formal analysis, G.F., T.R., C.I. and M.A.; data curation, F.V., G.F., T.R. and C.I.; writingoriginal draft preparation, F.V.; writing-review and editing, F.V., G.F., T.R., C.I., M.A., M.M. and M.L.; validation M.M. and M.L. All authors have read and agreed to the published version of the manuscript.

Funding: This research received no external funding.

Institutional Review Board Statement: Not applicable.

Informed Consent Statement: Not applicable.

Data Availability Statement: Supporting data can be provided under request.

Acknowledgments: A special acknowledgment goes to Fondazione Antonio Stradivari Museo del Violino and to the Conservator Fausto Cacciatori.

Conflicts of Interest: The authors declare no conflict of interest.

\section{References}

1. Fiocco, G.; Invernizzi, C.; Rovetta, T.; Albano, M.; Malagodi, M.; Davit, P.; Gulmini, M. Surfing through the coating system of historic bowed instruments: A spectroscopic perspective. Spectrosc. Eur. 2021, 33, 19-22. [CrossRef]

2. Invernizzi, C.; Fiocco, G.; Iwanicka, M.; Targowski, P.; Piccirillo, A.; Vagnini, M.; Licchelli, M.; Malagodi, M.; Bersani, D. Surface and interface treatments on wooden artefacts: Potentialities and limits of a non-invasive multi-technique study. Coatings 2021, 11, 29. [CrossRef]

3. Cacciatori, F. Antonio Stradivari, Disegni, Modelli e Forme-Catalogo Dei Reperti Delle Collezioni Civiche Liutarie del Comune di Cremona, Cremona; Fondazione Museo del Violino Antonio Stradivari: Cremona, Italy, 2016; ISBN 88-9091-795-0.

4. Invernizzi, C.; Daveri, A.; Rovetta, T.; Vagnini, M.; Licchelli, M.; Cacciatori, F.; Malagodi, M. A multi-analytical non-invasive approach to violin materials: The case of Antonio Stradivari 'Hellier' (1679). Microchem. J. 2016, 124, 743-750. [CrossRef]

5. Invernizzi, C.; Fiocco, G.; Iwanicka, M.; Kowalska, M.; Targowski, P.; Blümich, B.; Rehorn, C.; Gabrielli, V.; Bersani, D.; Licchelli, M.; et al. Non-invasive mobile technology to study the stratigraphy of ancient Cremonese violins: OCT, NMR-MOUSE, XRF and reflection FT-IR spectroscopy. Microchem. J. 2020, 155, 104754. [CrossRef]

6. Echard, J.P.; Benoit, C.; Peris-Vicente, J.; Malecki, V.; Gimeno-Adelantado, J.V.; Vaiedelich, S. Gas chromatography/mass spectrometry characterization of historical varnishes of ancient Italian lutes and violin. Anal. Chim. Acta 2007, 584, 172-180. [CrossRef]

7. Echard, J.P.; Bertrand, L.; Von Bohlen, A.; Le Hô, A.S.; Paris, C.; Bellot-Gurlet, L.; Soulier, B.; Lattuati-Derieux, A.; Thao, S.; Robinet, L.; et al. The Nature of the extraordinary finish of Stradivari's instruments. Angew. Chemie-Int. Ed. 2010, 49, 197-201. [CrossRef]

8. Nagyvary, J. The chemistry of a stradivarius. Chem. Eng. News 1988, 66, 24-31. [CrossRef]

9. Echard, J.P.; Lavédrine, B. Review on the characterisation of ancient stringed musical instruments varnishes and implementation of an analytical strategy. J. Cult. Herit. 2008, 9, 420-429. [CrossRef]

10. Rovetta, T.; Invernizzi, C.; Licchelli, M.; Cacciatori, F.; Malagodi, M. The elemental composition of Stradivari's musical instruments: New results through non-invasive EDXRF analysis. X-ray Spectrom. 2018, 47, 159-170. [CrossRef]

11. Rovetta, T.; Invernizzi, C.; Fiocco, G.; Albano, M.; Licchelli, M.; Gulmini, M.; Alf, G.; Fabbri, D.; Rombolà, A.G.; Malagodi, M. The case of Antonio Stradivari 1718 ex-San Lorenzo violin: History, restorations and conservation perspectives. J. Archaeol. Sci. Rep. 2019, 23, 443-450. [CrossRef]

12. Zumbühl, S.; Soulier, B.; Zindel, C. Varnish technology during the 16th-18th century: The use of pumice and bone ash as solid driers. J. Cult. Herit. 2021, 47, 56-68. [CrossRef]

13. Invernizzi, C.; Fichera, G.V.; Licchelli, M.; Malagodi, M. A non-invasive stratigraphic study by reflection FT-IR spectroscopy and UV-induced fluorescence technique: The case of historical violins. Microchem. J. 2018, 138, 273-281. [CrossRef] 
14. Su, C.; Chen, S.; Chung, J.; Li, G.; Brandmair, B.; Huthwelker, T.; Fulton, J.L.; Borca, C.N.; Huang, S.; Nagyvary, J.; et al. Materials Engineering of Violin Soundboards by Stradivari and Guarneri. Angew. Chemie Int. Ed. 2021, 60, 19144-19154. [CrossRef]

15. Obataya, E. Effects of natural and artificial ageing on the physical and acoustic properties of wood in musical instruments. J. Cult. Herit. 2017, 27, S63-S69. [CrossRef]

16. Tai, H.-C.; Chen, P.-L.; Xu, J.-W.; Chen, S.-Y. Two-photon fluorescence and second harmonic generation hyperspectral imaging of old and modern spruce woods. Opt. Express 2020, 28, 38831-38841. [CrossRef] [PubMed]

17. Cacciatori, F.; Sheets, A. Reunion in Cremona. Tesori dal "National Music Museum" Vermillion, South-Dakota al Museo del Violino; Catalogue edited by Fondazione Museo del Violino; Antonio Stradivari Cremona: Cremona, Italy, 2019.

18. Torrisi, F. Il 'Mandolino Coristo' di Antonio Stradivari La sua Rinascita a Cremona Nell'anno 2000; Cremona, Italy, 2002.

19. Rovetta, T.; Canevari, C.; Festa, L.; Licchelli, M.; Prati, S.; Malagodi, M. The golden age of the Neapolitan lutherie (1750-1800): New insights on the varnishes and decorations of ten historic mandolins. Appl. Phys. A Mater. Sci. Process. 2015, 118, 7-16. [CrossRef]

20. De la Rie, E.R. Fluorescence of Paint and Varnish Layers (Part I). Stud. Conserv. 1982, 27, 1-7.

21. De la Rie, E.R. Fluorescence of paint and varnish layers (Part II). Stud. Conserv. 1982, 27, 65-69.

22. Bonaduce, I.; Ribechini, E.; Modugno, F.; Colombini, M.P. Analytical Chemistry for Cultural Heritage; Springer International Publishing: Cham, Switzerland, 2017.

23. Artioli, G. Scientific Methods and Cultural Heritage: An Introduction to the Application of Materials Science to Archaeometry and Conservation Science; Oxford University Press: Oxford, UK, 2010.

24. Korte, E.H.; Staat, H. Infrared reflection studies of historical varnishes. Fresenius. J. Anal. Chem. 1993, 347, 454-457. [CrossRef]

25. Rosi, F.; Cartechini, L.; Sali, D.; Miliani, C. Recent trends in the application of fourier transform infrared (FT-IR) spectroscopy in Heritage Science: From micro: From non-invasive FT-IR. Phys. Sci. Rev. 2019, 4, 1-19. [CrossRef]

26. Dondi, P.; Lombardi, L.; Rocca, I.; Malagodi, M.; Licchelli, M. Multimodal workflow for the creation of interactive presentationsof 360 spin images of historical violins. Multimed. Tools Appl. 2018, 77, 28309-28332. [CrossRef]

27. Dondi, P.; Lombardi, L.; Invernizzi, C.; Rovetta, T.; Malagodi, M.; Licchelli, M. Automatic Analysis of UV-Induced FluorescenceImagery of Historical Violins. ACM J. Comput. Cult. Herit. 2017, 10, 1-13. [CrossRef]

28. Fiocco, G.; Gonzalez, S.; Invernizzi, C.; Rovetta, T.; Albano, M.; Dondi, P.; Licchelli, M.; Antonacci, F.; Malagodi, M. Compositional and morphological comparison among three coeval violins made by giuseppe guarneri 'del Gesù' in 1734. Coatings 2021, 11, 884. [CrossRef]

29. Beckhoff, B.; Kanngießer, B.; Langhoff, N.; Wedell, R.; Wolff, H. Handbook of Practical X-ray Fluorescence Analysis; Springer: Berlin/Heidelberg, Germany, 2006.

30. Poli, T.; Chiantore, O.; Nervo, M.; Piccirillo, A. Mid-IR fiber-optic reflectance spectroscopy for identifying the finish on wooden furniture. Anal. Bioanal. Chem. 2011, 400, 161-1171. [CrossRef] [PubMed]

31. Invernizzi, C.; Daveri, A.; Vagnini, M.; Malagodi, M. Non-invasive identification of organic materials in historical stringed musical instruments by reflection infrared spectroscopy: A methodological approach. Anal. Bioanal. Chem. 2017, 409, 3281-3288. [CrossRef]

32. Derrick, M.; Stulik, D.; Landry, J. Infrared Spectroscopy in Conservation Science; Getty Publications: Los Angeles, CA, USA, 1999.

33. Invernizzi, C.; Rovetta, T.; Licchelli, M.; Malagodi, M. Mid and near-infrared reflection spectral database of natural organic materials in the cultural heritage field. Int. J. Anal. Chem. 2018, 7823248, 1-16. [CrossRef]

34. Miliani, C.; Rosi, F.; Daveri, A.; Brunetti, B.G. Reflection infrared spectroscopy for the non-invasive in situ study of artists' pigments. Appl. Phys. A Mater. Sci. Process. 2012, 106, 295-307. [CrossRef]

35. Liu, Z.; Cao, J. Fabrication of superhydrophobic wood surface with a silica/silicone oil complex emulsion. Wood Res. 2018, 63, 353-364.

36. Fiocco, G.; Rovetta, T.; Gulmini, M.; Piccirillo, A.; Canevari, C.; Licchelli, M.; Malagodi, M. Approaches for detecting madder lake in multi-layered coating systems of historical bowed string instruments. Coatings 2018, 8, 171. [CrossRef]

37. Weththimuni, M.L.; Canevari, C.; Legnani, A.; Licchelli, M.; Malagodi, M.; Ricca, M.; Zeffiro, A. Experimental characterization of oil-colophony varnishes: A preliminary study. Int. J. Conserv. Sci. 2016, 7, 813-826.

38. Daher, C.; Paris, C.; Le Hô, A.S.; Bellot-Gurlet, L.; Échard, J.P. A joint use of Raman and infrared spectroscopies for the identification of natural organic media used in ancient varnishes. J. Raman Spectrosc. 2010, 41, 1494-1499. [CrossRef]

39. Daher, C.; Pimenta, V.; Bellot-Gurlet, L. Towards a non-invasive quantitative analysis of the organic components in museum objects varnishes by vibrational spectroscopies: Methodological approach. Talanta 2014, 129, 336-345. [CrossRef] [PubMed]

40. Mills, J.S.; White, R. Natural resins of art and archaeology their sources, chemistry, and identification. Stud. Conserv. 1977, 22, $12-31$.

41. Tai, B.H. Stradivari's Varnish A Review of Scientific Findings-Part I. J. Violin Soc. Am. VSA Pap. 2007, 21, 119-144.

42. Von Bohlen, A.; Meyer, F. Microanalysis of old violin varnishes by total-reflection X-ray fluorescence. Spectrochim. Acta-Part B At. Spectrosc. 1997, 52, 1053-1056. [CrossRef]

43. Echard, J.P. In situ multi-element analyses by energy-dispersive X-ray fluorescence on varnishes of historical violins. Spectrochim. Acta-Part B At. Spectrosc. 2004, 59, 1663-1667. [CrossRef]

44. Malagodi, M.; Canevari, C.; Bonizzoni, L.; Galli, A.; Maspero, F.; Martini, M. A multi-technique chemical characterization of a Stradivari decorated violin top plate. Appl. Phys. A Mater. Sci. Process. 2013, 112, 225-234. [CrossRef] 
45. Eastaugh, N.; Walsh, V.; Chaplin, T.; Siddall, R. Pigment Compendium A Disctionary and Optical Microscopy of Historical Pigments; Elsevier: Amsterdam, The Netherlands, 2013.

46. Canevari, C.; Delorenzi, M.; Invernizzi, C.; Licchelli, M.; Malagodi, M.; Rovetta, T.; Weththimuni, M. Chemical characterization of wood samples colored with iron inks: Insights into the ancient techniques of wood coloring. Wood Sci. Technol. 2016, 50, 1057-1070. [CrossRef]

47. Bonizzoni, L.; Canevari, C.; Galli, A.; Gargano, M.; Ludwig, N.; Malagodi, M.; Rovetta, T. A multidisciplinary materials characterization of a Joannes Marcus viol (16th century). Herit. Sci. 2014, 2, 15. [CrossRef]

48. Bulathsinghala, A.T.; Shaw, I.C. The toxic chemistry of methyl bromide. Hum. Exp. Toxicol. 2013, 33, 81-91. [CrossRef] [PubMed] 